Bangl. J. Vet. Med. (2008). 6 (2): 139-144

\title{
DETERMINATION OF IMMUNE RESPONSE OF IMPORTED NEWCASTLE DISEASE VIRUS VACCINES IN BROILER CHICKENS
}

\author{
M. S. Islam ${ }^{1}$, A. K. M. Khasruzzaman ${ }^{2}$, M. T. $\operatorname{Hossain}^{1}$, M. T. Islam ${ }^{1 \& 3}$, M. H. Chowdhury ${ }^{1}$, M. M. Rahman ${ }^{1}$, \\ M. A. Zinnah ${ }^{1}$, N. A. Banu ${ }^{1}$ and M. A. Islam ${ }^{1 *}$ \\ ${ }^{1}$ Department of Microbiology and Hygiene, ${ }^{3}$ Department of Medicine, Faculty of Veterinary \\ Science, Bangladesh Agricultural University, Mymensingh; ${ }^{2} \mathrm{CP}$ Bangladesh Co. Ltd. \\ *Corresponding author's e-mail address: alim_bau@ yahoo.co.in
}

\begin{abstract}
A study was undertaken to determine the immune response of eight different imported live NDV vaccines in broiler chickens in the Department of Microbiology and Hygiene, Bangladesh Agricultural University, Mymensingh during the period from July to December 2008. A total of 55 broiler chickens (Ross breed) were divided into eleven groups such as 1,2, $3,4,5,6,7,8,9,10$ and 11 of which group $1,3,5,7$ and 9 were vaccinated primarily with Nobilis ${ }^{\circledR}$ MA5+Clone 30 , Avipro ${ }^{\circledR}$ ND-IB HB1, Cevac ${ }^{\mathbb{B}}$ BIL, Newcastle-Bronchitis Vaccine Fortdodge ${ }^{\mathbb{B}}$ and Avipro ${ }^{\mathbb{B}}$ ND LaSota vaccine respectively at day 5 of age and secondarily with Nobilis ${ }^{\mathbb{B}}$ ND Clone 30 , Avipro ${ }^{\mathbb{B}}$ ND LaSota, Cevac ${ }^{\mathbb{B}}$ New L, Newcastle Disease vaccine Fortdodge $^{\circledR}$ and Avipro ${ }^{\circledR}$ ND LaSota vaccine respectively at day 21 of age by single eye instillation and 2, 4, 6, 8 and 10 were vaccinated with the same vaccines respectively by double eye instillation following the same schedule. Group 11 was kept as unvaccinated control. Sera samples were collected after 10 days of each vaccination and at day 5, 15, 20,31 of age from nonvaccinated control and subjected to $\mathrm{HI}$ test for the determination of antibody titres. It was observed that after primary vaccination the geometric mean $(\mathrm{GM})$ of $\mathrm{HI}$ titres of double eye vaccinated groups differed significantly $(\mathrm{P}<0.01)$. Overall analysis of GM of $\mathrm{HI}$ titres of double eye vaccinated groups revealed that there were significant increases $(\mathrm{P}<0.01)$ in $\mathrm{HI}$ titres in groups $8(301.07 \pm 70.10)$ and $10(284.24 \pm 85.86)$ compared to other groups. It was observed that secondary vaccination produced higher immune response compared to primary vaccination in case of all the vaccinated groups and double eye vaccination produced higher immune response compared to single eye vaccination in case of all the vaccinated groups. Maternal antibody was high $(256.00 \pm 140.21)$ at day 5 of age and persisted to a minimal level $(5.27 \pm 2.19)$ until the age of day 20 and almost disappears $(\leq 4 \pm 0)$ at day 31 of age. From the present research it may be concluded that LaSota strain produced higher immune response than Clone 30 and $\mathrm{B}_{1}$ strain and Fortdodge ${ }^{\circledR}$ and Avipro ${ }^{\circledR}$ vaccine produced higher immune response than all other vaccines used in this study.
\end{abstract}

Key words: Immune response, Newcastle disease, ND vaccines, broiler chickens

\section{INTRODUCTION}

Newcastle disease (ND) is one of the most important avian viral diseases because of its high economic impact on the poultry industry. The disease was initially reported in 1926 in Southeast Asia (Alexander, 1997) and since then it has become an economically important disease of poultry all over the world (Leslie, 2000). Newcastle disease is also considered as one of the major threat to the poultry raisers of Bangladesh too, because of its high morbidity, mortality and reduced productivity of poultry resulting remarkable economic losses every year since first isolation and identification of the virus in the year 1978 in Bangladesh by Hossain et al. (1978). The disease ND, is caused by Newcastle disease virus (NDV), which is characterized by sudden appearance and rapid spread of the virus within the flock with high morbidity and mortality. Newcastle disease virus is synonymous with avian paramyxovirus type 1 (APMV-1) and has been classified in the order Mononegavirales, family Paramyxoviridae, subfamily Paramyxovirinae, genus Rubulavirus (Alexander, 1997; Alexander, 1998 and Lamb et al., 1996). The virus is an enveloped, negative-sense, single-stranded RNA genome that encodes for six proteins including RNA dependent RNA polymerase (L), fusion (F) protein, hemagglutinin-neuraminidase $(\mathrm{HN})$ protein, matrix (M) protein, phosphoprotein (P), and nucleoprotein (NP) (De Leeuw et al., 1999). Clinically, NDV can be categorized into three main pathotypes i.e. lentogenic, mesogenic and velogenic strains (Alexander, 1997). Lentogenic strains, Asplin F, Hitchner $B_{1}$, and LaSota have low virulence, cause mild or inapparent respiratory or enteric infections, and are used for the preparation of live-virus vaccines. Mesogenic 
strains, Komarov (K), Mukteswar (M), DK 1155 of NDV mainly cause respiratory and nervous signs but not high mortality. Highly virulent NDV are termed as velogenic responsible for and infection can cause high mortality in chickens (Alexander, 1997). Velogenic strains (Herts 33; Texas GB; Bangladeshi field isolates) can be further divided into neurotropic or viscerotropic depending on the clinical signs and lesions associated with the infection (Alexander, 1997). The least pathogenic (Lentogenic) strains B $B_{1}$ (Hitchner et al., 1948), LaSota (Winterfield et al., 1957), and F (Asplin, 1952) are being used in birds of all ages through intra-nasally, intraocularly with drinking water, or spray. In the beginning of early 1990's the production of broiler have taken a shape of an industry in Bangladesh. Among poultry farming now broiler farming has become highly profitable and popular farming sector in Bangladesh. The financial returns from broiler farming are relatively quicker and it can produce animal protein in about one month from the day chickens are hatched. An efficient breed of broiler converts 1.6 to $1.8 \mathrm{Kg}$ of feed to produce one $\mathrm{Kg}$ of meat (Samad, 2005). The broiler meat is popular worldwide as it is palatable, easily digestible and flavourous; contain low fat and fibers. ND is a great problem for wider expansion of the broiler farming. Newcastle disease is an endemic in Bangladesh with high prevalence of viscerotropic velogenic strains (Chowdhury et al., 1982; Islam, 2003). According to Chowdhury et al. (1982), ND alone is responsible for at least $40-60 \%$ of total mortality of poultry population in Bangladesh. The control of ND relies on the regular use of safe and effective vaccines. Live vaccines prepared with lentogenic strains of NDV are now more commonly used in the broilers than vaccines prepared from chemically inactivated strains of NDV, mixed with adjuvant (Biggs et al., 1988; Alexander, 1997). Live freeze-dried NDV vaccines can be produced on a large scale at a relatively low cost. The vaccines are easy to administer on a large scale, and rapidly stimulate humoral, cell-mediated and mucosal immunity (Chandraseker, et al. 1989; Parry and Aitken, 1973). In Bangladesh, Livestock Research Institute (LRI) and some other pharmaceutical companies also produce NDV vaccine using lentogenic strains of NDV. Alongside with the vaccines produced in Bangladesh, quite a good number of live attenuated NDV vaccines prepared with the lentogenic strains and inactivated Newcastle disease virus vaccines are being imported and marketed by different pharmaceutical companies (ACI pharmaceuticals Ltd., CP Bangladesh Co. Ltd., Intervet pharmaceuticals Ltd., Advance animal health Ltd., Novartis pharmaceuticals Ltd. etc.). In Bangladesh farmers have been using various imported NDV vaccines following different schedule of vaccination. These imported vaccines are assumed to be highly effective against $\mathrm{ND}$ although there is paucity of information on the immune response of these vaccines. Considering the above factors, present study was undertaken to determine the immune response of imported NDV vaccines (live) commonly used in broiler chickens in Bangladesh, to observe the persistence of maternally derived antibody against NDV in broiler chickens and also to compare the immune response of broiler chickens against each of the imported live NDV vaccines used in this study.

\section{MATERIALS AND METHODS}

The whole experiment was conducted during the period from July to December 2008 in the Department of Microbiology and Hygiene, Faculty of Veterinary Science, Bangladesh Agricultural University, Mymensingh.

\section{Experimental chickens}

A total number of 55 day-old-chicks of Ross breed broiler with the history of parent stock vaccinated against Newcastle disease (ND) were collected from the CP Bangladesh Co. Ltd., Dhaka and reared in the experimental shed of the Department of Microbiology and Hygiene, BAU, Mymensingh. The birds were reared in litter supplying feed (Nourish ${ }^{\circledR}$ poultry feed) and water maintaining strict bio-security. Before vaccination the birds were divided into 11 groups each group consists of 5 birds.

\section{Newcastle disease virus vaccines}

Eight lyophilized (freeze-dried) Newcastle disease virus vaccines were procured from CP Bangladesh Ltd. and used in this study. These were (i) Nobilis ${ }^{\circledR}$ MA5+Clone30 vaccine (Clone30 and Massachusetts strain) of Intervet pharmaceuticals (ii) Avipro ${ }^{\circledR}$ ND-IB HB1 vaccine (B1 and Massachusetts strain) of Lohmann Animal Health (iii) Newcastle-Bronchitis Vaccine Fortdodge ${ }^{\circledR}$ (B1 and Massachusetts strain) of Fortdodge Animal Health (iv) Cevac ${ }^{\circledR}$ BIL vaccine (B1 and Massachusetts strain) of Ceva pharmaceuticals (v) Avipro ${ }^{\circledR}$ ND LaSota (LaSota strain) of Lohmann Animal Health (vi) Nobilis ${ }^{\circledR}$ ND Clone30 (Clone30 strain) of Intervet pharmaceuticals vii) Newcastle Disease Vaccine Fortdodge ${ }^{\circledR}$ (LaSota strain) of Fortdodge Animal Health (viii) Cevac ${ }^{\mathbb{B}}$ New L (LaSota strain) of Ceva pharmaceuticals. These vaccines were stored and diluted during use according to the instruction of the manufacturers. 


\section{Reference Newcastle disease virus (NDV) isolate}

Newcastle disease virus (Komarov strain) obtained from the laboratory repository of the Department of Microbiology and Hygiene, BAU, Mymensingh was propagated to activate the virus into 10-day-old embryonated chicken eggs through allantoic cavity route. AF was collected aseptically using sterile syringe and needle and transferred to sterile containers. The presence of NDV in AF was tested by slide HA test and those manifesting HA-positive were collected (Cottral, 1978) as a source of reference ND virus and stored at $-20^{\circ} \mathrm{C}$ until used.

\section{Vaccination schedule}

A total of 55 chickens were divided into eleven groups such as $1,2,3,4,5,6,7,8,9,10$ and 11 where each group contained 5 birds. Group 1, 3, 5, 7 and 9 were vaccinated primarily with Nobilis ${ }^{\circledR}$ MA5+Clone30, Avipro ${ }^{\circledR}$ ND-IB HB1, Cevac ${ }^{\circledR}$ BIL, Newcastle-Bronchitis Vaccine Fortdodge ${ }^{\circledR}$ and Avipro ${ }^{\circledR}$ ND LaSota vaccines respectively at day 5 of age and secondarily with Nobilis ${ }^{\circledR}$ ND Clone 30, Avipro ${ }^{\circledR}$ ND LaSota, Cevac ${ }^{\circledR}$ New L, Newcastle Disease vaccine Fortdodge ${ }^{\circledR}$ and Avipro ${ }^{\circledR}$ ND LaSota vaccines respectively at day 21 of age by single eye instillation and 2, 4, 6, 8 and 10 were vaccinated with the same vaccines respectively by double eye instillation following the same schedule. Group 11 was kept as unvaccinated control. Sera samples were collected after 10 days of each vaccination and at day 5, 15, 20,31 of age from non-vaccinated control and subjected to HI test for the determination of antibody titres.

\section{Haemagglutination inhibition (HI) test}

Micro-plate HI test was carried out (Anon, 1971) to determine the antibody level of each serum sample collected from the chicks of different groups. The test was conducted by using constant 4 HA unit ND virus and diluted serum ( $\beta$ method).

\section{Statistical analysis}

Statistical Package for Social Sciences (SPSS) version 10.0 programme was used for analysis the data. Repeated measures ANOVA was performed to find out the significant differences in HI antibody titres of different groups following vaccination. To locate significant differences between the means of HI titres of different groups Duncan's Multiple Range Test (DMRT) was initiated. Paired't' test was also performed to determine the significant differences in $\mathrm{HI}$ titres of chickens of a group after primary and secondary vaccination (Beri, 2007).

\section{RESULTS AND DISCUSSION}

Maternally derived antibody (MDA) was measured on a number of occasions starting from day 5 to day 31 and the titres are presented in Table 1. It was observed that the MDA persist to optimum level upto 15 days and reached at negligible level after 20 days of age. This finding strongly supports the findings of Shil (2006); Balla (1986); Saeed et al. (1988) and Islam et al. (2003) who stated that the persistence of MDA in broiler chickens were at day 15 to 20 of age. But Mahmud et al. (2007) reported that the persistence of MDA upto 27 days of age which may be due to the high MDA titre.

Table 1. Maternal antibody of unvaccinated control broiler chickens (Ross)

\begin{tabular}{|c|c|c|c|c|c|c|c|c|}
\hline \multirow{3}{*}{$\begin{array}{l}\text { No. of } \\
\text { serum } \\
\text { sample }\end{array}$} & \multicolumn{8}{|c|}{ Age of birds } \\
\hline & \multicolumn{2}{|l|}{ Day 5} & \multicolumn{2}{|c|}{ Day 15} & \multicolumn{2}{|c|}{ Day 20} & \multicolumn{2}{|c|}{ Day 31} \\
\hline & Titre & $\mathrm{GMT} \pm \mathrm{SD}$ & Titre & $\mathrm{GMT} \pm \mathrm{SD}$ & Titre & $\mathrm{GMT} \pm \mathrm{SD}$ & Titre & $\mathrm{GMT} \pm \mathrm{SD}$ \\
\hline 1 & 5127 & & 647 & & 8 & & $\leq 4$ & \\
\hline 2 & 256 & 256.00 & 48 & 49.65 & 4 & 5.27 & $\leq 4$ & $\leq 4 \pm 0$ \\
\hline 3 & 256 & \pm 140.21 & 48 & \pm 13.38 & 8 & \pm 2.19 & $\leq 4$ & \\
\hline 4 & 256 & & 64 & & 4 & & $\leq 4$ & \\
\hline 5 & 128 & & 32 & & 4 & & $\leq 4$ & \\
\hline
\end{tabular}

GMT $=$ Geometric mean titre, $\mathrm{SD}=$ Standard deviation. 
The principle goal of this study was to determine the immune response of imported live NDV vaccines in broiler chickens commonly used in Bangladesh. It was observed that the Geometric Mean (GM) of HI titres after primary vaccination were $97 \pm 35.05,105.20 \pm 28.62,97 \pm 35.05,99.31 \pm 26.77$ and $120.84 \pm 14.31$ in the birds of single eye vaccinated groups $1,3,5,7$ and 9 respectively and after secondary vaccination $147.03 \pm 85.86$, $150.53 \pm 82.82,215.41 \pm 35.05,168.89 \pm 70.10$ and $198.63 \pm 53.54$ respectively whereas in the birds of double eye vaccinated groups $2,4,6,8$ and 10 the GM of HI titres were $172.92 \pm 110.85,91.58 \pm 32,104.30 \pm 29.12$, $114.08 \pm 17.52$ and $228.17 \pm 35.05$ respectively after primary vaccination and $228.17 \pm 94.92,210.40 \pm 107.09$, $262.10 \pm 107.09,301.07 \pm 70.10$ and $284.24 \pm 85.86$ respectively after secondary vaccination (Table 2 ).

Table 2. Comparative HI titres of broiler chickens (Ross) following single and double eye vaccination with different NDV vaccines

\begin{tabular}{|c|c|c|c|c|c|}
\hline \multirow[t]{2}{*}{ Groups } & \multicolumn{2}{|l|}{ Vaccines used $^{\#}$} & \multicolumn{2}{|c|}{ Serum HI titre $(\mathrm{GMT} \pm \mathrm{SD})(\mathrm{n}=5)$} & \multirow{2}{*}{$\begin{array}{l}\text { Overall } \\
\text { significance } \\
\text { level }\end{array}$} \\
\hline & $\begin{array}{l}\text { Primary } \\
\text { vaccination }\end{array}$ & $\begin{array}{l}\text { Secondary } \\
\text { vaccination }\end{array}$ & $\begin{array}{l}\text { Post-primary } \\
\text { vaccination }^{\mathrm{A}} \\
\text { (15 days old) }\end{array}$ & $\begin{array}{l}\text { Post-secondary } \\
\text { vaccination }^{\mathrm{B}} \\
\text { (31 days old) }\end{array}$ & \\
\hline 1 & Nobilis $^{(R)}$ & Nobilis ${ }^{R} \mathrm{ND}$ & $97 \pm 35.05$ & $147.03 \pm 85.86$ & $\mathrm{C}$ \\
\hline 2 & MA5+Clone30 & Clone 30 & $172.92 \pm 110.85 \mathrm{a}$ & $228.17 \pm 94.92$ & $\mathrm{~B}$ \\
\hline 3 & Avipro ${ }^{\mathbb{R}} \mathrm{ND}-\mathrm{IB}$ & Avipro ${ }^{\circledR} \mathrm{ND}$ & $105.20 \pm 28.62$ & $150.53 \pm 82.82$ & $\mathrm{C}$ \\
\hline 4 & HB1 & LaSota & $91.58 \pm 32 b$ & $210.40 \pm 107.09 *$ & $\mathrm{BC}$ \\
\hline 5 & $\operatorname{Cevac}^{\circledR}$ BIL & Cevac ${ }^{B}$ New L & $97 \pm 35.05$ & $215.41 \pm 35.05 * *$ & $\mathrm{BC}$ \\
\hline 6 & & & $104.30 \pm 29.12 b$ & $262.10 \pm 107.09 *$ & $\mathrm{BC}$ \\
\hline 7 & Newcastle- & Newcastle & $99.31 \pm 26.77$ & $168.89 \pm 70.10$ & $\mathrm{C}$ \\
\hline \multirow[t]{3}{*}{8} & Bronchitis & Disease & $114.08 \pm 17.52 b$ & $301.07 \pm 70.10^{* *}$ & $\mathrm{AB}$ \\
\hline & Vaccine & Vaccine & & & \\
\hline & Fortdodge $^{\circledR}$ & Fortdodge $^{\circledR}$ & & & \\
\hline 9 & Avipro ${ }^{\circledR} \mathrm{ND}$ & Avipro ${ }^{\circledR} \mathrm{ND}$ & $120.84 \pm 14.31$ & $198.63 \pm 53.54 *$ & $\mathrm{BC}$ \\
\hline 10 & LaSota & LaSota & $228.17 \pm 35.05 \mathrm{a}$ & $284.24 \pm 85.86$ & A \\
\hline
\end{tabular}

$\mathrm{n}=$ Number of sera samples tested; GMT $=$ Geometric mean; SD $=$ Standard deviation.

${ }^{\#}$ Dose and route of vaccination $=$ Odd number groups - one drop in one eye, even number groups - one drop in each eye.

${ }^{\text {A }}$ Primary vaccination of all the groups was done at 5 days old.

${ }^{\mathrm{B}}$ Secondary vaccination of all the groups was done at 21 days old.

Figures with different letter within same column differ significantly $(\mathrm{p}<0.01)$.

**Significant at $\mathrm{p}<0.01$.

*Significant at $\mathrm{p}<0.05$.

Among all the vaccines of different strains, it was found that after primary vaccination chickens of the group vaccinated with LaSota strain produced higher immune response than the chickens of other groups vaccinated with $B_{1}$ or Clone 30 strains. This finding is in agreement with Almassy et al. (1979) and Westbury (1984) who reported that LaSota strain provided superior antibody production after vaccination compared to that of $\mathrm{B}_{1}$. It was observed that after secondary vaccination the HI antibody titres increased significantly $(\mathrm{p}<0.01)$ compared to primary vaccination. The increase in antibody titres recorded after secondary vaccination in the present study highly agree with the observation of Rahman et al. (2004) who reported that HI antibody titre in chickens immunized with $\mathrm{V}_{4} \mathrm{HR}-\mathrm{ND}$ vaccine significantly $(\mathrm{p}<0.01)$ increased after booster vaccination.

In the present study, it was observed that double eye vaccinated groups of broiler chickens produced significantly higher immune response $(\mathrm{p}<0.01)$ compared to those of single eye vaccinated groups of chickens. This increase immune response might be due to the higher number of virus present in each dose. The vaccine virus concentration was higher in double eye dose than the single eye dose which might be played a vital role in the production of higher immune response. For better immune response the dose of vaccine is important factor 
which helps to increase the level of immunity also reported by Bankowski and Hill (1954); Crawley (1954a,b); Winterfield and Seadle (1957). Overall analysis of the results of the present study consideration among the vaccinated groups it was noticed that the HI titres of birds of group 8 vaccinated primarily with NewcastleBronchitis Vaccine Fortdodge ${ }^{\circledR}$ and secondarily with Newcastle Disease Vaccine Fortdodge ${ }^{\circledR}$ by double eye dose and group 10 vaccinated primarily and secondarily with Avipro ${ }^{\circledR}$ ND LaSota by double eye dose were significantly $(\mathrm{p}<0.01)$ higher than all other vaccinated groups. Thus, considering the above findings it may be mentioned that Fortdodge ${ }^{\circledR}$ vaccine and Avipro ${ }^{\circledR}$ vaccine (Lohmann Animal Health) produced higher immune response than the other six vaccines used in this study.

\section{ACKNOWLEDGEMENT}

The authors are thankful to CP Bangladesh Co. Ltd., for financial help for the study.

\section{REFERENCES}

1. Alexander DJ (1997). Newcastle disease and other paramyxoviridae infections. In: Diseases of poultry, $10^{\text {th }}$ edn., BW Calnek, HJ Barnes, CW Beard, LR McDougald, and YM Saif (eds). Iowa State University press, Ames, USA. pp. 541569.

2. Alexander DJ (1998). Newcastle disease virus and other paramyxoviruses. In: A laboratory manual for the isolation and identification of avian pathogens, $4^{\text {th }}$ edn. DE Swayne, JR Glisson, MW Jack-wood, JE Pearson and WM Reed (eds). American Association of Avian Pathologists, Kennett Square, PA. pp. 156-163.

3. Almassyl K, Barhouma N, EI-Sabbgh A, Ibrahim SN, Boktor N, Khashaba E and Gawad SA (1979). Comparative immunization experiments with lentogenic Newcastle disease vaccine strain. Journal of Egyptian Veterinary Medical Association 35: 95-104

4. Anon. (1971). Methods for examining poultry biologics and for identifying and quantifying avian pathogens. Newcastle Disease, p. 66. National Academy of Science, Washington, D. C.

5. Asplin FD (1952). Immunization against Newcastle disease with a virus of low virulence (strain F) and observation of subclinical infection in partial resistant fowls. Veterinary Record 64: 245-49.

6. Balla L (1986). Use of standardized HI test for monitoring immunity to Newcastle disease I. Experiments to standardize the HI test II. Antibody response after different immunization schedules. Magyar Allatorvosok Lapja 41: 98-109.

7. Bankowski RA and Hill RW (1954). Factor influencing the efficiency of vaccination of chickens against Newcastle disease by the air borne route. Proc. $91^{\text {st }}$ Ann. Meet. American Associ. Scattle. pp. 317-327.

8. Beri GC (2007). Business Statistics. $2^{\text {nd }}$ edn., Tata McGraw-Hill publishing Co. Ltd., New Delhi. pp.1-727.

9. Biggs PM, Box PG, Brown F, Mcconnel I, Mcferren JB and Soulsby EJL (1988). Vaccination in the control of infectious diseases in farm animal-BVA trust project: Future of animal health control edited by Smith, H \& Payne, J.M. UK. pp. 21-27.

10. Chandraseker S, Vankatesan RA, Padmanaban VD, Masslliamony PR (1989). Nature of protective immunity response in chicken against Ranikhet disease. Indian Veterinary Journal 66: 801-806.

11. Chowdhury SI, Chowdhury TIMFR, Sarker AJ, Amin MM and Hossain WIMA (1982). Studies on Newcastle disease in Bangladesh. A Research Report, Sec 2. The role of residual maternal antibody on immune response and selection of an optimum age for primary vaccination of chicks. Bangladesh Veterinary Journal 16: 12-22.

12. Cottral GE (1978). Manual of standardized methods for veterinary microbiology. Cornell University press, Ithaca. N.Y. pp. 47-52.

13. Crawley JF (1954a). Immunization of chickens against infectious bronchitis and Newcastle disease by the spray method. Papers presented to $10^{\text {th }}$ Worlds Poultry Congress. Edinburgh. pp. 234-237.

14. Crawley JF (1954b). Incidence of Newcastle disease in Canadian Poultry Flocks during 1952-1953. Canadian Journal Comparative Medicine 18 (4): 128-130.

15. De Leeuw O and Peeters B (1999). Complete nucleotide sequence of Newcastle disease virus: evidence for the existence of a new genus with in the subfamily Paramyxovirinae. Journal of General Virology 80: 131-136.

16. Hitchner SB and Johnson EP (1948). A virus of low virulence for immunizing fowls against Newcastle disease (Avian Pneumoencephalitis). Veterinary Medicine 43 (12): 525-530.

17. Hossain WIMA, Chowdhury TIMF, Amin MM and Rahman MM (1978). Pathogenic characteristics of two selected isolates of Newcastle disease virus from Bangladesh. Bangladesh Veterinary Journal 12 (1-4): 35 - 42.

18. Islam MR, Huque QME, Giasuddin M, Alam J and Rahman MM (2003). Assessment of Maternal derived antibody of commercial flock against Newcastle disease. Proceedings of $3^{\text {rd }}$ international poultry show and seminar, Bangladesh china Friendship Conference center, Dhaka, Bangladesh. pp. 89-93.

19. Lamb RA and D Kolakofsky (1996). Paramyxoviridae: the viruses and their replication. In: Fields virology, $3^{\text {rd }}$ edn., B. N. Fields, D. M. Knipe, and P.M. Howley, (eds). Lippincott-Raven Publ., Philadel-phia, PA. pp. 1177-1204.

20. Leslie J (2000). Newcastle disease: outbreak losses and control policy costs. Veterinary Record 146: 603-606. 
21. Mahmud MS, Hossain MT, Monoura P and Amin MM (2007). Comparative efficacy of Avinew (VG/GA strain) and BCRDV (F strain) vaccines against Newcastle disease in broiler chickens. Bangladesh Journal of Veterinary Medicine 5 (1\&2): 19-23.

22. Parry SH and Aitken ID (1973). Immunoglobulin A in the respiratory tract of the chicken following exposure Newcastle disease virus. Veterinary Record 93: 258-260.

23. Rahman MB, Rahman MM, Rahman M, Kabir SLM, Nazir KHMNH and Amin MM (2004). Efficacy of $V_{4} H R$ Newcastle Disease $\left(\mathrm{V}_{4} \mathrm{HR}-\mathrm{ND}\right)$ vaccine in broiler birds in Bangladesh. International Journal of Poultry Science. 3 (5): 365-368.

24. Saeed Z, Ahmad S, Rizvi AR and Ajmal M (1988). Role of maternal antibody in determination of an effective Newcastle disease vaccination programme. Pakistan Journal of Veterinary Research 1: 18-21.

25. Samad MA (2005). Poultry Science and Medicine, $1^{\text {st }}$ edn., LEP publication. BAU campus, Mymensingh. pp. 170-192.

26. Shil NC (2006). Evaluation of the antibody production following single vaccination with BCRDV, Izovac $B_{1}$ Hitchner and Cevac New L in broiler chicks. M.S thesis June-2006. Department of Microbiology and Hygiene, Bangladesh Agricultural University, Mymensingh.

27. Westbury HA (1984). Comparison of the immunogenicity of NDV strains V4, B1 and LaSota in chickens. 1. Tests in susceptible chickens. Australian Veterinary Journal 61: 5-9.

28. Winterfield RW and Seadale EH (1957). The immune response of chickens vaccinated at an early age with $\mathrm{B}_{1}$ Newcastle disease virus administered through the drinking water under field condition. Poultry Science. 36: 65-70. 